\title{
Evidensbasert pedagogisk praksis: Utvalgte kontroverser
}

\author{
Tone Kvernbekk* \\ Universitetet $i$ Oslo, Norge
}

\section{Sammendrag}

Evidensbasert praksis (EBP) er en stor tematikk med forgreninger i mange retninger, for eksempel epistemologi, metode, normativitet, kausalitet, rom for skjønn, forskningens rolle overfor praksis, etc. Ikke overraskende er uenigheten stor. I denne artikkelen diskuterer jeg fire utvalgte kontroverser: Hva «basert» betyr, evidensbegrepet, instrumentalitet og standardisering av praksis. Det finnes naturligvis flere kontroverser, men nettopp i disse er det mange misforståelser ute og går. Artikkelen er tenkt å bidra til oppklaring av ulike misforståelser, men også til nødvendig nyansering og tvisyn om EBP.

Nøkkelord: Evidens; kausalitet; mål-middel; skjønn; tiltaksintegritet

\begin{abstract}
Evidence-based practice (EBP) comprises a multitude of topics and has many ramifications, including epistemological, methodological, normative and ontological ones. Not surprisingly disagreement reigns. In this article I discuss four selected controversies: What "based" might mean, the concept of evidence, instrumentality, and the standardization of practice. These four are selected because they, as I see it, are the home of many misunderstandings. This article aims to help clarify matters, and to contribute to more nuanced discussions about EBP.
\end{abstract}

Keywords: Causality; evidence; fidelity; judgment; means-end; stability

Mottatt: Februar, 2018; Antatt: Juni, 2018; Publisert: August 2018

Vi lever i en tid som insisterer på at alle former for praksis og policy skal være basert på forskning og evidens. Forskere møter krav fra politisk hold om å skape bedre og mer forskningsbasert kunnskap, og praktikere møter krav fra politisk hold om å bruke forskning til å skape ønskverdige resultater eller forbedre eksisterende resultater. I dette bildet finner vi også evidensbasert praksis (EBP), først etablert i medisin rundt midten av 1990-årene. Kjernen i EBP handler om hvordan vi skal frambringe ønskverdige resultater og forebygge uønskverdige resultater. Man ønsker med andre

\footnotetext{
^Korrespondanse:Tone Kvernbekk, Postboks 1092 Blindern, 0317 OSLO. Epost: tone.kvernbekk@ iped.uio.no
} 
ord å vite hva som «virker». Fokus på hva som virker, er naturligvis ikke noe nytt i pedagogisk praksis, men en tematikk som til alle tider har vært sentral i mange (men ikke alle) hverdagsaktiviteter som praktikere er involvert i. Man har mål som skal nås, og ønsker å vite beste mulige måte å nå disse på. Det går derfor fint an å tenke seg at EBP skulle være et velkomment innslag i pedagogikken - ikke minst fordi det er et område hvor forskningen kan gjøre seg selv nyttig for praksis, noe pedagogisk forskning ofte blir beskyldt for ikke å være. Ikke desto mindre er EBP mye kritisert. Det er noe med EBP som gjør at det får både ihuga tilhengere og ihuga kritikere.

EBP er et område med mange forskjellige temaer og problemer med forgreninger $\mathrm{i}$ mange retninger, og hvor tilhengere og kritikere har kryssende perspektiver, antakelser og verdistandpunkter. Innflytelsesrike forskere som Robert Slavin (2002, 2004) argumenterer for at rigorøs forskning over tid vil gi samme framgang i pedagogikk som medisin har hatt, fordi alle intervensjoner testes og evalueres grundig før de tas i bruk. John Hatties metaanalyser om hva som virker inn på læring, er både kjente og omstridte (Hattie, 2009, 2012), og her i Norge er Thomas Nordahl kjent som en sterk støttespiller for EBP (f.eks. Nordahl, 2010). De mest kjente kritikerne er nok Gert Biesta (f.eks. 2007, 2010) og Martyn Hammersley (f.eks. 2007), som også er svært innflytelsesrike. Disse skal jeg komme tilbake til. Til dels har kritikere og tilhengere også svært forskjellig vokabular. I det vanlige begrepsmessige landskapet som omgir EBP, finner vi begreper som «det virker», effektivitet, målbarhet, resultatoppnåelse, kunnskapsbase, evidenshierarki, forskningsbasering, tiltak, tiltaksintegritet, randomiserte kontrollerte forsøk, etc. Opp mot dette vokabularet setter kritikerne gjerne et annet vokabular som består av praktisk vurdering, profesjonelt skjønn, kontekstavhengighet, etiske overveielser, moralsk praksis, etc. Ofte finner vi her en uuttalt antakelse om at disse vokabularene er uforenlige, og at det siste står i fare for å bli erstattet av det første. Midt i alle forgreninger og vokabularer er det viktig å holde fast ved at EBP i utgangspunktet er praktisk orientert, og sier at vår praksis, for eksempel tiltak vi iverksetter, skal være basert på evidens som forteller hvor godt tiltaket virker.

Jeg skal i denne artikkelen diskutere fire utvalgte kontroverser, hvor noen av de sentrale navnene på feltet spiller en rolle, andre ikke. Disse er ikke på noen måte uttømmende for kontroversene rundt EBP, men de er problemområder hvor jeg mener det er mange misforståelser ute og går, både blant tilhengere og kritikere: Hva «basert» betyr, evidensen og dens funksjon, instrumentalitet samt standardisering av praksis. Jeg er verken ihuga tilhenger eller ihuga kritiker. Jeg har som utgangspunkt at det er mer fornuft i EBP enn hva kritikerne tror, men at det også er betydelig mer komplekst enn hva tilhengerne tror. EBP er en komplisert affære som trenger tvisyn, nyanser og mangefasetterte tilnærminger.

\section{Hva «basert» betyr}

En av kontroversene rundt EBP gjelder forholdet mellom evidens og praksis, som uttrykkes i selve termen. Hva betyr det å basere praksis på evidens? Dette forgrener 
seg også til rollen pedagogisk forskning skal ha for praksis, og hva slags funksjon man tror at evidens har eller skal ha. En tidlig EBP-entusiast som David Hargreaves mener eksempelvis at pedagogisk forskning skal bidra til å forbedre praksis. I sin kjente (og i ettertid beryktete) tale til det britiske Teacher Training Agency (TTA) i London redegjør han for sine synspunkter. Pedagogikken, sier han, trenger forskning som:

[...] (i) demonstrates conclusively that if teachers change their practice from $\mathrm{x}$ to $\mathrm{y}$ there will be a significant and enduring improvement in teaching and learning and

(ii) has developed an effective method of convincing teachers of the benefits of, and means to, changing from $x$ to $y$ (1996a, s. 5).

Her er det et par ting å merke seg. For det første ser Hargreaves for seg at forskningen har (eller bør ha) en direkte innflytelse på praksis. Slik kan den være nyttig for lærere, skolepolitikere, skoleeiere, rektorer og andre. Det som er nyttig å vite, er hva som virker, og det er nettopp det lærere ønsker å vite, mener Hargreaves. Bare sekundært er de interessert i å forstå hvorfor noe virker. For det andre skal vi merke oss den store styrken han tillegger forskning (evidens): Den kan vise en gang for alle (conclusively) at metode y er bedre enn metode $\mathrm{x}$. I en senere publikasjon forsterker han dette til conclusive and decisive (1996b).

Det er mye som tyder på at mange kritikere tolker «basert» på samme måten. Evidensen utgjør en konkret «base» eller et konkret «fundament» (f.eks. Davies, 2003), og «basert på» forstås som "derivert fra». Relasjonen mellom evidens og praksis kan med andre ord beskrives som derivasjon - evidensen forteller deg hva du skal gjøre. Men mens tilhengerne kan mene at dette er bra fordi det fører til praksis som virker, finner kritikerne det urovekkende. Gert Biesta (2007, 2010) er en sterk kritiker av EBP. Han tillegger tilhengerne av EBP følgende oppfatning:

[They] think that research will be able to give us "the truth» and that "the truth» can be translated into rules for action, and that the only thing practitioners need to do is to follow these rules without any further reflection on or consideration of the concrete situation they are in (2007, s. 11).

Altså: Evidens gir oss «sannheten», og ut fra denne kan vi utlede regler for hvordan vi skal handle i praksis. Tenkning ut over det er unødvendig. Vi finner en lignende forståelse hos Martyn Hammersley (1997). Han tillegger EBP-tilhengere som Hargreaves den oppfatningen at evidens kan utgjøre et fundament man kan utlede handlingsregler av, og denne oppfatningen er han dypt uenig i. Undervisning (teaching) kan ikke baseres på evidens eller forskningsbasert kunnskap, sier Hammersley. Han har to beslektete begrunnelser for dette synspunktet. Den første er at han mener at flesteparten av de utfordringene lærere står overfor, ikke lar seg forske på, ettersom bare «tekniske» problemer er åpne for forskning. Den andre er at undervisning ikke er teknisk, men praktisk/etisk: «... it is a matter of making judgements rather than following rules» (s. 147). 
På mange måter ser vi her de to ulike vokabularene i sving. Praktisk vurdering, profesjonelt skjønn og etiske overveielser settes opp mot effektivitet og måloppnåelse. Det er et gjennomgående tema i Hargreaves' publikasjoner at praksis bør/må forbedres slik at elevene oppnår bedre resultater, og resultater er generelt forstått som målbar «output». Men til tross for insisteringen på den direkte forbindelsen mellom forskning og praksis kan man ikke beskylde ham for å støtte ureflektert regelfølging; det er også et gjennomgående tema for ham at evidens skal øke kvaliteten på profesjonelle vurderinger, ikke erstatte dem. Jeg skal komme tilbake til regelfølgingsproblemet i den fjerde utvalgte kontroversen, da i en litt annen kontekst.

I de senere årene har man begynt å erstatte evidensbasert med evidensinformert, $\mathrm{i}$ den hensikt å gi mer rom for praktikernes dømmekraft. Det er helt åpenbart at ordet «basert» er misvisende; vi kan ikke derivere praksis eller handlingsregler fra data. Da er det mindre strengt og mer fleksibelt å kalle det for «informert» i stedet. Men selv Hargreaves insisterer altså på at evidens skal støtte praktikernes dømmekraft, ikke erstatte den. Og faktisk er det slik at hva vi tenker at evidensen skal gjøre for oss, ikke automatisk blir klarere av å si at den skal informere. Vi må derfor se nærmere på hva evidens er, og hva slags funksjon den har.

\section{Evidensbegrepet}

Av og til ser det ut som om «evidens» har fått sitt eget liv. Den får noen ganger nesten agentstatus, en selvstendig rolle, den kan reise fra land til land, den betraktes som et fundament, som vi så over, og tillegges en egen kausal kraft. For eksempel hadde tidsskriftet Asterisk (som utgis av DPU ved Aarhus Universitet) i 2014 et spesialnummer med tittelen «Bliver du styrket af evidens?», og i lederen spør Hanne Løngreen om evidensbegrepet styrker eller svekker lærere og pedagoger (2014, s. 2). Det er fort gjort at diskusjonen om EBP blir til diskusjoner om man er for eller mot evidens, og det er uheldig, sier Løngreen. Jeg er enig med Løngreen i at for-mot-diskusjoner ikke er opplysende. Jeg vil dessuten hevde at det er meningsløst å være mot evidens. Thomas Aastrup Rømer, som er dypt kritisk til EBP, skriver at evidensbegrepet er fremmed for pedagogikken, at det ikke finnes i pedagogisk teori, at det ikke har noen tradisjon bak seg, og at det ikke har noen rolle å spille i pedagogiske sammenhenger (Rømer, 2012). Ingen av disse påstandene er riktige, slik jeg ser det, og hvorfor vil komme fram i den følgende argumentasjonen. Det er for så vidt korrekt at begrepet evidens ikke er et pedagogisk begrep og slik sett ikke figurerer i pedagogisk teori, men evidensmessige betraktninger må åpenbart inngå både i utvikling og evaluering av pedagogisk teori.

Mens EBP i sitt vesen er praktisk, tilhører evidensbegrepet epistemologien og befinner seg i et begrepsmessig landskap som også inneholder hypotese, oppfatning, legitimering, begrunnelse, sannhet, bekreftelse, støtte, falsifisering, induksjon, sannsynlighet, etc. - altså et annet vokabular enn de to som innledningsvis ble antydet. Hva sier så epistemologien om begrepet evidens? Jo, den sier at evidens er det som 


\section{Tone Kvernbekk}

støtter sannhetsgehalten av en teori (påstand, oppfatning, hypotese), slik at grunnfunksjonen kan oppsummeres i ordet støtte (Achinstein, 2001; Kelly, 2008). Evidens er alltid evidens for noe, det vi bruker og henviser til når vi avgjør om en teori er sann eller usann, bekreftet eller avkreftet. Positiv evidens indikerer at hypotesen er riktig, negativ evidens indikerer at hypotesen er usann. Ofte bruker vi ikke ordet evidens, men heller termer som er nære slektninger av evidens: grunner, begrunnelse, belegg. Evidens inngår mer eller mindre uanstrengt i alle former for hverdagslig tenkning og kunnskapsdannelse - for eksempel var sjokoladen sønnen min hadde i ansiktet og på fingrene evidens for hypotesen om at det var han som hadde tjuvstartet på bestemors bursdagskake (selv om han nektet blankt). De som leser krim, vet at evidens kan være mye rart: alt fra fotavtrykk og registrerte bompasseringer til DNA og rekonstruerte tidslinjer som viser at mistenkte ikke kunne ha vært der han påsto han var på et bestemt tidspunkt.

Det viktigste med evidens er dens funksjon. Evidens er en tjener. For det vi er interesserte i, er hypotesen eller oppfatningen som evidensen er evidens for. Evidensen skal hjelpe oss å vurdere om hypotesen er troverdig eller ikke, sann eller usann, og da er vi framme ved evidensens mest sentrale egenskap: Den må være pålitelig. Evidens som er dårlig, svak eller direkte feil kan ikke brukes til å støtte en hypotese. Det er med andre ord viktig å vurdere kvaliteten på den framlagte evidensen. Det er ingen grunn til å ta den for gitt, verken i forskningen eller i hverdagen.

Vitenskapsteoretikeren Peter Achinstein (2001) skiller mellom fire forskjellige typer evidens som alle befinner seg innenfor hovedfunksjonen støtte. Alle typene er i bruk i forskning, sier han. Typifiseringen er interessant, ikke minst fordi den faktisk er vanskelig å karakterisere. Den er for eksempel helt ulik evidenshierarkiene man ofte opererer med i EBP, og den handler heller ikke hvem som bestemmer hva som kan gjelde som evidens, som er mye diskutert i EBP (f.eks. Gamson, 2007). Hovedsakelig plasserer Achinstein de fire typene langs to dimensjoner: en objektiv-subjektiv dimensjon og en styrkedimensjon. La oss se kort på de ulike typene. Den første kaller Achinstein for epistemic situation (ES) evidence (s. 21). Dette er særlig relevant i historisk forskning, når vi spør om det var legitimt av en forsker å tro på hypotese $\mathrm{H}$, gitt hva slags informasjon han eller hun ellers hadde tilgang til, faktisk visste, eller ikke kunne vite fordi det ble oppdaget senere, etc. ES-evidens er en objektiv form for evidens, sier Achinstein, og med det mener han at evidensen er evidens for $\mathrm{H}$ for enhver person som er i en slik epistemisk situasjon. Hypotesen kan naturligvis vise seg å være usann, selv om den støttes av evidens. Det å støtte sannhetsgehalten i en hypotese er ikke det samme som å garantere den.

Den andre typen evidens er subjektiv og relativisert til en person eller en gruppe (s. 23). Gruppen tror at evidens $\mathrm{E}$ er evidens for hypotese $\mathrm{H}$, de tror at $\mathrm{H}$ er sann, og grunnen til at de tror at $\mathrm{H}$ er sann, er at de tror at $\mathrm{E}$ er sann. E må ikke være sann; dette er et subjektivt begrep om evidens, så det er tilstrekkelig at gruppen tror det.

Den tredje typen evidens kaller Achinstein for veridical (s. 26). Dette er et objektivt evidensbegrep (objektiv betyr det samme her som under ES-evidens) og verdt 
å stoppe opp ved fordi det er den sterkeste typen evidens. I slike sammenhenger er både $\mathrm{E}$ og $\mathrm{H}$ sanne, sier Achinstein. Evidensen er med andre ord fullkomment pålitelig, helt entydig og har stor styrke, og ettersom den gir oss grunn til å tro på $\mathrm{H}$, så er $\mathrm{H}$ også sann. Achinstein tror at dette er den formen for evidens som forskere egentlig vil ha, ettersom de ønsker at teoriene deres skal være sanne både generelt og objektivt, og ikke begrenset til den konkrete situasjonen evidensen ble samlet inn i. Det må være en slik forståelse Biesta tillegger EBP-tilhengere når han sier at de tror at evidens gir sannhet. Og Hargreaves kan bringes inn igjen her; han ønsker seg forskning som «demonstrates conclusively that if teachers change their practice from $\mathrm{x}$ to $\mathrm{y}$ there will be a significant and enduring improvement in teaching and learning» (1996a, s. 5, min utheving), og forsterker altså dette senere til conclusive and decisive (1996b). Da må han forutsette at evidens er veridical, at den er objektiv og har en kolossal styrke. Achinstein på sin side skiller mellom veridical og conclusive evidens og sier i klare ordelag at conclusive er for sterkt. Hvis evidensen er conclusive, så er ikke bare $\mathrm{H}$ sann, men evidensen etablerer $\mathrm{H}$ med sikkerhet, en gang for alle. Det er allmenn enighet i vitenskapsteorien om at dette er å ta altfor hardt i, og at feilbarlighet er et viktig prinsipp å ha. Sikkerhet er for lengst kastet ut av vitenskapen og erstattet med sannsynlighet. Men her finnes det finurligheter, noe jeg skal komme tilbake til.

Achinsteins fjerde og siste type evidens kalles potential (s. 28). Slik evidens er objektiv, og den er sann, men svakere enn veridical fordi den ikke krever at $\mathrm{H}$ må være sann. $\mathrm{H}$ kan altså være feil selv om E støtter den. Potential evidens gjør det sannsynlig at $\mathrm{H}$ er sann, men garanterer det ikke.

Etter min mening bringer Achinstein til torgs en nyansert oppfatning av evidensbegrepet, og at potential peker seg ut som et fornuftig grunnbegrep om evidens. Alle Achinsteins evidenstyper er empiriske og omfatter for eksempel ikke logiske, etiske eller estetiske grunner, som jo også i prinsippet kan brukes til å støtte hypoteser eller teorier. I tillegg til dimensjonene de er kategorisert etter, peker typene peker mot fire viktige temaer: 1) at evidens alltid opptrer i relasjon til en teori/hypotese, 2) at denne relasjonen handler om støtte, ikke fundament, 3) at påliteligheten av evidensen er avgjørende, og 4) at det er teorien/hypotesen vi egentlig er mest interessert i. Disse må vi holde fast ved, fordi de på en grunnleggende måte viser hva evidensmessige relasjoner handler om. Men de er ikke tilstrekkelige i en EBP-kontekst, for EBP er praktisk orientert.

Jeg setter problemene med «basert» og innsiktene fra epistemologien sammen til følgende oppfatning: Praksis er ikke basert på evidens, men på hypotesen/teorien som evidensen er evidens for. Det er den vi er interesserte i, og det er den som implementeres i praksis, og som vi tenker skal «virke». Men verken tilhengere eller kritikere diskuterer hva slags hypotese dette kan være. I stedet diskuteres det hva som kan tenkes å gjelde som evidens i EBP (f.eks. Gamson, 2007; Oancea \& Pring, 2008). Disse to spørsmålene henger nært sammen, ettersom hva som kan brukes som evidens, er avhengig av hva slags hypotese man vil ha evidens for - ulike påstander krever ulike former for evidens. Her får vi ikke noen hjelp av Achinstein, som holder seg på et 


\section{Tone Kvernbekk}

overordnet nivå i sine utlegninger. Achinstein diskuterer heller ikke metode, noe som er en svakhet i framstillingen hans - metode henger nært sammen med ikke bare evidensens styrke og pålitelighet, men også dens rekkevidde. I EBP-litteraturen er det slik at både tilhengere og kritikere $\mathrm{i}$ det store og hele er enige om at gangbar evidens i EBP kommer fra randomiserte kontrollerte forsøk (RCT, randomized controlled trials), og dermed utgjøres av kvantitative data. Og da er vi framme ved det såkalte evidenshierarkiet, som brukes til å rangere evidens. Evidenshierarkier kan ha litt ulik utforming, men samtlige rangerer evidens fra RCT-er og metaanalyser øverst og erfaring og profesjonelt skjønn nær bunnen. Det er ikke vanskelig å forstå at de som setter praktikeres skjønn og dømmekraft i sentrum for profesjonsutøvelse, stiller seg kritisk til evidenshierarkiene.

Dette må vi se litt nærmere på. Det er særlig to spørsmål som reiser seg. Det første er hvilke kriterier som er grunnlaget for rangeringen. Svaret på det er at evidenshierarkier rangerer evidens etter dens pålitelighet (Cartwright \& Hardie, 2012). Pålitelig evidens gir oss, som vi så over, god grunn til å tro at hypotesen er sann. Pålitelighet henger sammen med metode. Hierarkiene sier at evidens som stammer fra RCT-er er pålitelig evidens, og at verken erfaring eller profesjonelle skjønnsvurderinger er helt til å stole på. Det andre spørsmålet er hva slags hypotese evidensen skal være evidens for i EBP. Hvilken forskningsmetode man skal bruke, og hvilken evidens som er relevant, avhenger naturligvis av hva slags problemstilling man har. Dette later til å være et glemt prinsipp i EBP-debatten. Det ser heller ut som om evidenshierarkiene har en tendens til å bli oppfattet som generelle, og ikke begrenset til utvalgte typer problemstillinger (f.eks. Oancea \& Pring, 2008).

Så hva er det vi vil ha evidens for i EBP? For å formulere det, må vi gå tilbake til den praktiske kjernen i EBP: Man ønsker å vite hva som «virker». Men «hva som virker» er en nokså vag formulering, og noe «virker» alltid bare i forhold til noe annet. Vi kan i første omgang presisere det til «tiltak $\mathrm{X}$ fører til resultat $\mathrm{Y}$ » (for da sier vi at $\mathrm{X}$ «virker»). Dette er en generell hypotese om en kausal sammenheng mellom X og Y. Og det er en slik hypotese vi implementerer i EBP; det vil si at vi iverksetter $\mathrm{X}$, og det gjør vi fordi vi har evidens som tilsier at da får vi resultat Y. Det er åpenbart mye som kan anvendes som evidens for en slik hypotese, også erfaring og profesjonelt skjønn. Men her har faktisk evidenshierarkiet en berettigelse. I EBP har vi med kausale hypoteser å gjøre, og RCT-er gir pålitelig evidens for å kunne trekke kausale slutninger. I slike forsøk sammenligner vi grovt sett en forsøksgruppe og en kontrollgruppe som er antatt å være like på alle kausalt relevante faktorer unntatt én - tiltaket (X). Så sammenligner vi effekten av tiltaket på de to gruppene, og hvis vi finner en forskjell i gjennomsnittlig resultat (effektstørrelsen), tolker vi den kausalt og tilskriver den tiltak $\mathrm{X}$. Og her er finurligheten: RCT-er gir meget sterke data. Faktisk gir de veridical, ja til og med conclusive evidens, hvis vi skal tro Nancy Cartwright (2007). En ideell RCT er bygd opp slik at hvis alle de spesifikke antakelsene er oppfylt (f.eks. om vellykket randomisering), vil et positivt resultat deduktivt innebære konklusjonen. Forskningsdesignet garanterer evidens $\mathrm{E}$, som dermed er sann; E garanterer hypotese $\mathrm{H}$, som 
dermed også er sann. RCT-er har med andre ord høy grad av indre validitet, selv om ikke alle antakelsene skulle være oppfylt (og det er de vel ytterst sjelden). Men denne indre validiteten går på bekostning av ytre validitet, sier Cartwright. Evidens som er så sterk, har også liten rekkevidde. Strengt tatt gjelder den bare for gruppene som deltok i forsøket. Så mens RCT-er egner seg til kausale studier fordi de skiller mellom korrelasjon og kausalitet og lar oss isolere tiltaket og studere effekten av det, er evidensen bare evidens for en meget begrenset hypotese. Dette lager naturligvis problemer for EBP, hvor man gjerne ønsker at den kausale hypotesen skal gjelde generelt. Men evidens fra en RCT er ikke evidens for en generell kausal hypotese (at et tiltak virker allment), den er evidens for en mye mer begrenset påstand, nemlig at tiltaket virket i forsøket.

Da må vi gå tilbake til spørsmålet om hva vi vil ha evidens for i EBP. Hva ønsker praktikere å vite om et eventuelt tiltak som kan settes i verk? De vil vite om det virker her, i deres klasserom, for deres elever, tror jeg. Og det forteller ikke den forskningsbaserte evidensen dem, og heller ikke om den kommer fra metaanalyser og omfatter flere RCT-er. Elever er ulike, klasserom er ulike, lærere er ulike, skoler er ulike, og man kan ikke predikere om et tiltak vil virke på samme måten her selv om det virket et eller annet sted. Derfor hevder jeg at den forskningsbaserte evidensen bare forteller halve historien (Kvernbekk, 2016). Resten av historien er lokal og må fortelles av praktikeren. En praktiker som vurderer å iverksette et bestemt tiltak, må spørre seg selv hva sannsynligheten er for at det vil virke i den lokale konteksten, og da må RCT-evidensen utfylles med lokal evidens. Kan mine elever nyttiggjøre seg dette? Passer det for dem? Har vi ressursene som skal til? Kan jeg enkelt skaffe dem hvis jeg ikke har dem til rådighet? Får jeg foreldrene med meg, hvis tiltaket forutsetter hjemmearbeid? Med andre ord, den evidensen som til sjuende og sist skal støtte en hypotese om sannsynligheten for at $\mathrm{X}$ vil virke her, er svært heterogen. Den utgjøres av RCT-evidens, kontekstuell evidens, lærerens kunnskaper om sine elever, etc. Og da har vi kommet en lang vei både fra kritikernes ideer om evidens som basis og utledete handlingsregler og fra tilhengernes antakelser om at forskningsbasert evidens er alt man trenger.

\section{Instrumentalitet}

Dette problemområdet handler ikke om evidens, men om relasjonen mellom tiltak og (ønsket) resultat og hvordan den skal oppfattes. EBP hører hjemme i en stor internasjonal trend med fokus på resultater og måloppnåelse, vurdering, måling, testing og dokumentasjon. Derfor har EBP et klart anstrøk av mål-middel-tenkning, med tiltak som middel og ønsket resultat som mål. Instrumentalitetsproblematikken som sådan er uavhengig av EBP og har vært mye diskutert og kritisert i pedagogisk sammenheng, for eksempel av Hans Skjervheim (1992). Det er kanskje ikke riktig å kalle dette temaet for en EBP-kontrovers, i og med at det reises av kritikere, og så vidt jeg kan se ikke diskuteres av tilhengere. Det er godt mulig at tilhengere av EBP tar 
mål-middel-tenkning for gitt, og ser det som en utbredt og legitim tenkemåte. Instrumentalitet er en ingrediens i alle former for planlegging hvor vi har et mål og grubler på hvordan vi skal nå det, og jeg skal i dette avsnittet forsvare mål-middel-tenkningen.

Omdreiningspunktet er hvordan relasjonen mellom mål og midler skal oppfattes. Gert Biesta mener at EBP innebærer følgende ide om praksis:

... a technological process in which there is a clear separation between means and ends, and in which it is assumed that the ends are given and the only relevant (professional and research) questions pertain to the most effective and efficient way of achieving those ends (2007, s. 9).

Det er uklart hva Biesta mener med "teknologisk prosess", men jeg er enig med ham i at det er her vi finner EBP: midler til å oppnå mål. John Elliott (2004) er like kritisk til mål-middel-tenkning. EBP (eller outcomes-based education i sin alminnelighet) innebærer en form for praksis som ikke skal være noe annet enn et effektivt middel for å oppnå mål, sier han, og midlenes effektivitet bestemmes på basis av empirisk evidens. Videre sier han:

The determination of means requires a clear and precise pre-specification of ends as tangible and measurable outputs or targets, which constitute quality standards against which the performance of social practitioners is to be judged (2004, s. 169).

Jeg skal ikke her diskutere fastsettelse av mål eller hvem som har rett til å gjøre det, men jeg ønsker å signalisere et potensielt problem som EBP-kritikere gjør helt rett i å påpeke: en mulig bevegelse tilbake fra middel til mål. Når måling av resultater blir sentralt, oppstår det en risiko for at vi setter mål som lar seg måle, og unngår mål som ikke (enkelt) lar seg måle.

Det er to hovedmåter å forstå relasjonen mellom mål og midler på: som konstituerende og som instrumentell. Biesta mener at relasjonen er instrumentell i EBP, mens den i all genuin pedagogisk virksomhet egentlig er konstituerende:

$\ldots$ in education means and ends are not linked in a technological or external way but [...] are related internally or constitutively. The means we use in education are not neutral with respect to the ends we wish to achieve. It is not the case that education can simply use any means as long as they are "effective" (2007, s. 10).

Dette siste punktet er åpenbart sant. Man skal ikke bruke midler bare fordi de er effektive. Men det er feil å framstille det som noe som er definert inn i EBP, slik Biesta gjør.

Hva kan det så bety at midler er konstitutive for målet? Det kan i alle fall ikke bety at midler bidrar til målet, for det vil gjøre dem til separate størrelser som dermed er eksternt og ikke internt relatert. Epistemologen Robert Audi definerer konstituering på følgende måte: «preserving one's life out of the duty to do so is not an ordinary causal means to fulfilling that duty, it constitutes fulfilling it» (1991, s. 67). 
Middelet eller aktiviteten bidrar ikke til målet, men er en konkret instansiering av det, en eksemplifisering. Dette kjenner vi også igjen fra egenverditenkningen. Vi leser poesi for poesiens egen skyld, fordi den har verdi i seg selv, ikke fordi vi skal oppnå noe annet ved å gjøre det. Egenverdi innebærer at midler og mål er ett, at man ikke kan skille på dem fordi det å drive med middelet utgjør selve målet. De er internt relatert, som Biesta uttrykker det.

En del pedagogisk aktivitet faller inn under en slik tenkning. EBP gjør det ikke; det har Biesta rett i. I EBP ligger det en annen forståelse av mål-middel-relasjonen, nemlig som separat eller ekstern. Vi trenger jo ikke empirisk forskning for å finne midler til et mål hvis middelet konstituerer målet, og det gir ikke mening å spørre om et middel «virker» hvis det er en eksemplifisering av målet. Men det følger ikke av dette at mål-middel-tenkning ikke har noen plass i pedagogikken, og heller ikke at EBP må forkastes, slik Biesta synes å mene.

Når mål og midler er instrumentelt relatert, driver vi med aktiviteten (middelet) for å oppnå noe annet. Målet ligger utenfor selve aktiviteten. Det betyr at målet kan nås på mange forskjellige måter. Dette er en praktisk, jordnær tenkemåte som gjennomsyrer dagliglivet og den praktiske pedagogikken, og det er ikke noe galt i det. Målet er å dra på jordomseiling; middelet er å spare penger, ta ekstra oppdrag og leve sparsommelig. Målet er å lære elevene å lese; middelet er ulike leseopplæringsmetoder. Vi sier at et middel har instrumentell verdi hvis det er effektivt og bidrar til at vi oppnår målet. Kritikere som Gert Biesta (2007, 2010) og Ian Sanderson (2003) mener at det eneste relevante kriteriet for midler i EBP er deres effektivitet. Biesta går så langt at han tillegger EBP den oppfatningen at hvis et middel er funnet å være effektivt, er det dermed også obligatorisk (mandatory) å bruke det:

I have argued that to suggest that research about "what works" can replace such judgments [læreres praktiske skjønn, forf.anm.] not only implies an unwarranted leap from "is" to "ought", but also denies practitioners the right not to act according to evidence about "what works" if they judge that such a line of action would be educationally undesirable (2007, s. 20).

Dette er å ta usedvanlig hardt i. Jeg vet ikke om noen EBP-tilhengere som har foreslått at midler skal være obligatoriske på denne måten, og jeg kan ikke forestille meg noen som vil gjøre det. Det forholdet at det finnes et mulig effektivt middel til et mål skaper i seg selv ingen forpliktelse til å bruke det. Ikke desto mindre tror jeg at Biesta har bygd dette elementet inn i sin definisjon av EBP, og dermed tar dette for å være noe som EBP simpelthen innebærer. Men det er ingen grunn til å definere EBP på denne måten. Da ville det knapt finnes konkrete praksiser som faller inn under EBP-begrepet, og den enkle definisjonen som ble lansert i begynnelsen av denne artikkelen inneholder definitivt ikke dette elementet.

Det hersker mange antakelser om mål-middel-tenkning, og jeg mener at mange av dem er misforståelser. For det første later det til å være en utbredt antakelse at midler enten har egenverdi eller instrumentell verdi, og at instrumentell verdi på noe 


\section{Tone Kvernbekk}

vis er mindreverdig. Men det er åpenbart slik at en aktivitet kan ha både egenverdi og instrumentell verdi samtidig, som når elever som arbeider med poesi både blir interessert i litteratur og tilegner seg leseferdigheter på en gang. Og gitt betydningen og frekvensen av instrumentell resonnering i dagliglivet, er det ingen grunn til å avvise den. Men, og her er det et viktig men: Det er helt essensielt å holde egenverditenkningen i hevd og passe på at instrumentell tenkning ikke får spise seg inn på dens område. Alt kan ikke og skal ikke gjøres til gjenstand for instrumentell tenkning.

For det andre later det til å være en utbredt antakelse at etiske overveielser er utelukket hvis man tenker instrumentelt (se f.eks. Sanderson, 2003). På dette punktet kan det være instruktivt å innhente synspunkter fra argumentasjonsteori; der føres det nyanserte diskusjoner som illustrerer kompleksiteten i instrumentell tenkning. Argumentasjonsteoretikeren David Hitchcock (2011, s. 8) foreslår at resonnering fra mål til midler bør inneholde følgende elementer: (1) Mål M er ansett for å være ønskverdig, og aktøren har til hensikt å frambringe eller oppnå det. Dette er det jeg innledningsvis kalte for kjernen i EBP, selve definisjonen på hva EBP er (man kan også ha til hensikt å forebygge noe som anses som uønskverdig). (2) Aktøren må så tenke ut hva slags midler som kan tenkes å bidra til dette målet. Midlene kan være mangfoldige og omfatte læreres handlinger, metoder, artefakter, elevaktiviteter, etc. (3) Midlene må være tilgjengelige i situasjonen. (4) De må også være tillatte og akseptable; det vil si at de ikke bryter med etiske, juridiske eller institusjonelle regler og verdier. Dette er et vesentlig element som fortjener ekstra kommentar. Hitchcock bygger altså etiske overveielser inn i instrumentelle resonnementer, mens både Biesta og Sanderson ser ut til å forutsette at det ikke er rom for etiske overveielser verken i mål-middel-tenkning eller i EBP, ettersom evidens bare sier noe om effektivitet. Det er ikke instrumentalitet og effektivitet som teller i pedagogikken, sier Sanderson, det er det som er passende eller riktig (appropriate) som teller. Og disse er på grensen til å være uforenlige: «Secondly, by conceiving of rationality in terms of means to given ends, [instrumental actions] neglect the ethical-moral dimension of problem-solving» (2003, s. 40). Dette er nært beslektet med Biestas synspunkt som er gjengitt over: hans påstand om at praktikere er utelukket fra å vurdere andre sider ved midler enn de rent instrumentelle. Men man får naturligvis trekke inn etiske synspunkter, både i instrumentell tenkning og i EBP. (5) Aktøren må overveie om det finnes alternative midler til målet, altså andre og kanskje bedre måter å nå det på. (6) Til slutt må aktøren vurdere mulige bieffekter av middelet. Etter at alle disse elementene er gjennomtenkte, veies de sammen i en beslutning om å bruke middelet (eller å la være). Det er med andre ord mange kriterier som er relevante å bruke for å vurdere midler i EBP: ikke bare deres effektivitet, men også normative og praktiske forhold. Målmiddel-tenkning er med andre ord mer kompleks enn den ofte antas å være. Men som vi skal se i neste avsnitt, er det beslektete faktorer i landskapet rundt EBP som gir grunn til bekymring.

For det tredje er det en utbredt antakelse at mål-middel-tenkning er problematisk fordi den er kausal (se f.eks. Skjervheim, 1992). Kausalitet er bakt inn i Hitchcocks 
element (2): at midler skal bidra til målet, gjøre det sannsynlig at mål $M$ kan oppnås i den aktuelle konteksten. EBP er åpenbart kausal, derom kan det ikke herske noen tvil. Bidra er bare ett av mange kausale verb vi har til rådighet i EBP og i pedagogikk i sin alminnelighet; andre eksempler er øke, redusere, påvirke, motivere, iverksette tiltak, frambringe, hindre, forebygge, intervenere, virke. Det man er ute etter i EBP, er en relasjon mellom midler og mål (input og output, årsak og virkning) som er slik at hvis vi iverksetter middelet, fører det til målet. Om et middel fører til målet, sier vi at det «virker», at det er effektivt.

Det er mye filosofisk støy rundt kausalitet. Når det gjelder EBP, tror jeg at tilhengere og kritikere paradoksalt nok deler mange antakelser, men at de vurderer dem så å si motsatt (f.eks. Biesta, 2007, 2010; Hargreaves, 1996a, 1996b). De vanligste antakelsene om kausalitet i dette feltet er at årsaker er tilstrekkelige, stabile, generelle, og at kausale relasjoner holder i seg selv, uavhengig av kontekstuelle faktorer (Kvernbekk, 2016). Hvis årsaker hadde slike egenskaper, ville de være formidable kandidater til pedagogiske midler - da kan man bruke dem til å planlegge for (nesten) garantert oppnåelse av ønskverdige mål. En årsak (et middel) som er tilstrekkelig for virkningen, vil føre til virkningen hver gang den brukes. Det vil en tilhenger mene er effektivt, forutsigbart, anvendelig til planlegging, og derfor bra. En kritiker vil kunne vurdere det som manipulering eller indoktrinering, og derfor ikke bra.

For en rekke kritikere, inkludert Gert Biesta, er kausalitet en selvstendig grunn til å avvise EBP. Pedagogisk praksis er moralsk i sitt vesen, og derfor er kausalitet utelukket per definisjon, mener han. Dette bygger på en antakelse om at kausalitet ikke bare er deterministisk, men også fysisk («push and pull»), bare til bruk i naturvitenskap og ikke i samfunnsvitenskap. Alle disse antakelsene er feil, vil jeg hevde. På dette punktet har tilhengerne av EBP rett; kausalitet har en helt legitim plass i EBP. Og i all praktisk pedagogikk, vil jeg legge til for egen regning. Vi har mål vi ønsker å nå, vi må kunne planlegge hvordan vi skal gjøre det, vi ønsker at gode resultater skal være reproduserbare, og det forutsetter helt grunnleggende kausalitet. På den andre siden er tilhengerne av EBP ofte overoptimistiske; det ser man lettest på bruken av uttrykket «føre til» (lead to) («Hvis vi giør slik, vil det føre til at ...») eller på generaliteten i kausale påstander. Et eksempel på det siste kan være Dean, Hubbell, Pitler og Stone: «Providing feedback on homework assignments benefits students, particularly when that feedback is in the form of written comments or grades» (2012, s. 107). Diskusjonene deres av ulike pedagogiske strategier røper at de tar det for gitt at strategiene (årsakene, midlene) er generelle, og derfor virker allment. Det er det jo ikke sikkert at de gjør. Vi må holde oss med et nyansert, allsidig og fleksibelt kausalitetsbegrep. Kausalitet er et mangefasettert fenomen; det eksisterer et antall ulike og til dels motstridende teorier og definisjoner. Kausalitet er en dynamisk relasjon hvor årsaker noen ganger produserer sine effekter, andre ganger ikke; årsaker kan bidra mer eller mindre til en effekt; de samspiller alltid med kontekstuelle faktorer hvorav noen kan hindre effekten; de trenger ofte tid for å virke, etc. (Kvernbekk, 2016). I det hele tatt er ting mer kompliserte og uforutsigbare enn tilhengerne har en tendens til å tro. 


\section{Tone Kvernbekk}

For å oppsummere: Instrumentalitet er en bestemt forståelse av hvordan midler er relatert til mål. Som ordet antyder, er midler å oppfatte som redskaper, instrumenter, og det innebærer at mål og midler er separate, de er eksternt og kausalt relatert. Her befinner EBP seg. Pedagoger (og andre) som er skeptiske til instrumentalitet og kausalitet, er derfor per definisjon også skeptiske til EBP. Tilhengerne av EBP later til å ta både instrumentalitet og kausalitet for gitt. De opererer i regelen ikke med noe eksplisitt kausalitetsbegrep, men har en del antakelser som er problematiske. Mitt standpunkt er at både instrumentalitet og kausalitet har en plass i pedagogikken og derfor også i EBP. Det er viktig å tenke nøye gjennom hvordan man skal forstå kausalitet. Og det er livsviktig å beholde et rom for egenverditenkning - noen ting gjøres for sin egen del, og ikke for noe annet. Å tenke framtidsrettet hele tiden kan legge for store byrder på framtiden.

\section{Standardisering av praksis}

Standardisering er en tematikk som inkorporerer mye av det som er diskutert så langt. Kritikerne bekymrer seg med rette, synes jeg - jeg vurderer også dette til å være et av de mest problematiske punktene i EBP. Utgangspunktet er imidlertid greit; de som driver pedagogisk og annen profesjonell praksis, ønsker å kunne nå oppsatte/vedtatte mål på en forutsigbar, pålitelig og effektiv måte. Jeg skal i det følgende diskutere to ulike perspektiver på standardisering: stabilitet og tiltaksintegritet. Vi begynner med stabilitet og et systemteoretisk blikk.

Forutsigbar, pålitelig og effektiv måloppnåelse forutsetter at praksis, situasjonen eller konteksten er stabil. Hvis den er urolig, kaotisk eller omskiftende, kan ikke for eksempel en leseopplæringsmetode forventes å virke (selv om den virket fint der den ble testet ut). Stabilitet i situasjonen er et tema som ikke diskuteres noe særlig, verken av tilhengere eller kritikere av EBP, men som åpenbart må være sentralt i en praktisk orientert tenkemåte som EBP. En måte å skape stabilitet på er å lage rutiner, vaner eller standardiserte prosedyrer. I takt med utbredelsen av EBP har det vokst fram såkalte What Works Clearinghouses, som blant annet har som oppgave å minske avstanden mellom forskning og praksis. De skal syntetisere og systematisere forskning og på basis av disse oversiktene lage anbefalinger for hvordan ting kan/bør/skal gjøres i praksis, ut fra hva evidensen sier om hvilke metoder som virker best. Slike anbefalinger kan så utgjøre standardiserte prosedyrer som, når man legger dem til grunn, kan skape en stabilitet i den aktuelle konteksten (klasserommet) som gir intervensjonen (middelet, metoden) tid og rom til å virke. Slike anbefalinger kan ha ulik grad av spesifisitet, fra generelle retningslinjer til spesifikke oppskrifter - de varierer med andre ord fra kan gjøre via bør gjøre til må gjøre. Innenfor en slik ramme er kritikernes bekymring for det profesjonelle skjønnet og praksis som regelfølging forståelig.

Stabilitet i konteksten er nødvendig. Men når tipper nødvendig stabilitet over i kontraproduktiv rigiditet? Her kan systemteori gi et interessant perspektiv, og jeg skal anvende Gregory Batesons (1972) tvillingbegreper stabilitet og fleksibilitet. Det kan 
synes paradoksalt å behandle stabilitet og fleksibilitet sammen; det er lett å tenke at de står i motsetning til hverandre, eller er trusler for hverandre. Men for Bateson forutsetter de hverandre. Det er to hovedgrunner til at en kontekst må holdes stabil, sier Bateson. Den ene er, som jeg allerede har vært inne på, at pedagogiske handlinger/ metoder/tiltak skjer i en konkret kontekst, og interagerer med faktorer i denne konteksten, og hvis konteksten er kaotisk og skiftende klarer ikke metoden/tiltaket å gjøre jobben sin. Den andre er at ethvert system eller enhver kontekst må holde seg stabil rundt en kjerne av verdier for å opprettholde sin egen identitet. Og for å holde seg stabilt må et system være fleksibelt. Fleksibilitet er en dyrebar ressurs, sier Bateson, den utgjør alltid et foreløpig uutnyttet potensial for endring. For å illustrere relasjonen mellom stabilitet og fleksibilitet bruker han en linedanser som metafor. Jeg er svært glad i denne metaforen og gjengir hele Batesons beskrivelse:

To maintain the ongoing truth of his basic premise («I am on the wire»), he must be free to move from one position of instability to another, i.e., certain variables such as the rate of movement of his arms must have great flexibility, which he uses to maintain the stability of other more fundamental and general characteristics. If his arms are fixed or paralyzed [...], he must fall (Bateson, 1972, s. 498).

Analogien med pedagogisk praksis er som følger: Det systemet vi kan kalle pedagogisk praksis, har også en grunnleggende sannhet å opprettholde: for eksempel tillit mellom lærer og elev, respekt, selvstendighet, rom for kreativ og kritisk tenkning. Fleksibilitet finnes i alle de små og store endringene og justeringene som konstant må gjøres for å holde dette fundamentale systemet stabilt. Men lærerens fleksibilitet kan spises opp av standardiserte prosedyrer, regler, testing, regelmessig måling av kunnskaper og detaljerte målformuleringer, etc., siden de for eksempel kan tvinge læreren til å gjøre ting på samme måte framfor å endre, tilpasse eller skreddersy opplegg. Hvis rommet for mulige interaksjoner mellom elever, lærer og omgivelser krymper, kan man i verste fall ende opp med at det bare er én mulig/tillatt måte å gjøre ting på. «Teaching to the test» er ganske vanlig, så testing kan føre til begrensninger i hva som anses for verdifulle klasseromsaktiviteter.

Det å båndlegge fleksibiliteten i et system begrenser hvilke muligheter som kunne ha blitt realisert. Jeg tror nok ikke at fleksibilitetstapet ved innføring av standardiserte prosedyrer er så stort at systemets kjerneverdier er truet; det beror på hvor standardiserte de er. Men ett sted når man et punkt der legitim stabilitet glir over i illegitim rigiditet, og et rigid pedagogisk system kan ikke opprettholde sin identitet som pedagogisk, og kan heller ikke opprettholde kjerneverdiene sine. Hvis vi lager regler for hvordan linedanseren skal få bruke armene for å holde balansen, kommer han til å falle.

Det andre perspektivet på standardisering er såkalt tiltaksintegritet (fidelity). Her finner vi antakelser om både evidens og kausalitet, men til sjuende og sist er dette et ontologisk spørsmål. Det handler om hvordan man tror verden er.

Tiltaksintegritet er et krav om «trofasthet» i implementering: Hvis praktikere skal implementere et tiltak som forskningen sier at virker, så skal det implementeres 


\section{Tone Kvernbekk}

nøyaktig slik det er implementert andre steder, eller slik tiltaksutviklerne foreskriver at det skal gjøres. PALS (Positiv atferd og støttende læringsmiljø i skolen) kan være et eksempel. Det er et stort og sammensatt tiltak, bestående av mange komponenter, det skal brukes på en hel skole, og det trenger to-tre år på å virke (Arnesen, Ogden \& Sørlie, 2006). Tiltakspakken bestemmes i forkant, og det gjør også implementeringen, men noen lokale justeringer tillates. Men de som skal implementere, må være lojale mot prosedyrene som er fastlagt. Hvis tiltaket iverksettes på en annen måte enn det som er bestemt, vet vi ikke lenger nøyaktig hva det er som virker, mener Arnesen, Ogden og Sørlie. Hvis implementering ikke skjer som planlagt, er det ikke sikkert at tiltaket produserer sine planlagte, forventete resultater, og utviklerne av tiltaket kan ikke holdes ansvarlige for de resultater som da måtte komme. Variasjoner i effektiviteten av PALS mellom skoler skyldes som regel, men ikke alltid, avvikende eller usystematisk implementering, sier forfatterne (2006, s. 27).

Men hva er det egentlig som er involvert i dette kravet om "trofasthet»? Er det nødvendig for forutsigbar måloppnåelse, at resultater fra ett sted kan reproduseres et annet sted? Jeg er enig med kritikerne av EBP om at dette er problematisk. Ikke av omsorg for praktikernes skjønn, men fordi jeg har en annen ontologisk oppfatning enn den som ligger til grunn for kravet om trofasthet. Hvis det skal gi mening å forlange trofasthet i implementering, slik at framgangsmåten fastsettes på forhånd (og er så å si lik fra sted til sted), forutsetter det to ting: Den ene er at det er tiltaket alene som har effekt, den andre er at mottakerne er så like at tiltaket kan spille samme kausale rolle i en ny kontekst som det gjorde i den forrige, eller der det ble testet ut. Dette beror jo på hvordan man tror at verden er. Hvis man tror at elever er ganske like, har samme egenskaper, reagerer likt på input, etc., kan man med rimelig stor sikkerhet predikere resultatet. Hvis man snarere tror at verden er mangfoldig og utviser stor variasjon, kan man ikke ta det for gitt at et tiltak som har virket ett sted, også vil virke et annet sted. Her er det viktig å tenke konkret kontekst og huske at hypotesen vi ønsker evidens for, er en hypotese om at tiltaket vil virke her, for mine elever. Her kopler denne ontologiske tematikken seg sammen med den evidensen som kommer fra RCT-er, som det ble antydet i diskusjonen av evidensbegrepet. RCT-er forteller oss ikke hva som virker allment eller generelt; de forteller oss hva som skjedde der forsøket ble foretatt. Hvis vi ikke har noen grunn til å tro at distribusjonen av kausale og andre egenskaper er den samme hos mine elever, har vi heller ingen grunn til å tro at et tiltak vil virke her på samme måten (Cartwright \& Hardie, 2012). Hvor vanskelig man tenker seg at det er å svare på spørsmålet «vil tiltaket virke her», avhenger av hvor dyptgående man tror at kontekstuelle forskjeller er. Og der er folk naturlig nok ulike.

Ontologiske synspunkter inkluderer kausalitet. Jeg tror som sagt at kausalitet finnes, og at den lar seg anvende i pedagogiske sammenhenger. Samtidig tror jeg ikke at årsaker er spesielt stabile i sine effekter. Noen ganger oppnår vi ønsket resultat, andre ganger ikke. Noen ganger kan vi forklare hvorfor (det var sterke hindrende faktorer i systemet), andre ganger kan vi det ikke. Verden, inkludert den pedagogiske, er indeterministisk. I tillegg kommer at tiltak, handlinger, midler, læringsstrategier, 
etc., alltid skjer i konkrete kontekster. De føres inn i en allerede eksisterende praksis og vil måtte interagere med faktorer som allerede er til stede, for å virke. I forskning kan man «nøytralisere» disse (ved å randomisere), i praksis kan man ikke det. Hvordan et tiltak utspiller seg og hvilken effekt det får, avhenger derfor også av faktorene i konteksten. Forskerne vet ikke hvilke faktorer som befinner seg i konkrete kontekster hvor praktikere skal iverksette et foreslått tiltak - det er det praktikerne som vet. De må gjøre en vurdering av tiltaket, innhente evidens om det, og så avgjøre om de tror at tiltaket kan spille en positiv kausal rolle i deres kontekst og bidra til oppnåelse av ønskverdige mål. Forskning kan være komplisert nok, men praksis er mye mer komplisert, vil jeg si. Kravet om "trofasthet» (fidelity) er problematisk fordi det ikke ivaretar mangfold og variasjon i pedagogiske fenomener og blant individer, og gjør seg antakelser om kausalitet som er vanskelige å forsvare. Men i rettferdighetens navn må det sies at Arnesen, Ogden og Sørlie (2006) også tillater en viss kontekstuell justering, selv om prosedyrer og rekkefølge på tiltakskomponentene er forhåndsbestemt. Som et siste moment kan vi notere at det ikke er helt klart nøyaktig hva det er vi skal være trofaste mot. Pedagogiske prinsipper, retningslinjer og regler kan befinne seg på ulike abstraksjonsnivåer. Er de oppskrifter som skal følges til minste detalj, på nøyaktig samme måte? Jeg vil tro at det er dette både Biesta og Hammersley sikter til når de snakker om regelfølging. Eller har prinsipper mer form av generelle retningslinjer, som åpenbart tillater ulike manifestasjoner i praksis? Disse rommer mye mer fleksibilitet. Jeg konkluderer med at praksis ikke prinsipielt kan standardiseres, $\mathrm{i}$ betydningen gjøres lik. Men man kan sørge for en noenlunde riktig grad av stabilitet.

\section{Avslutning}

Evidensbasert praksis er et fascinerende tema. Det har forgreninger $i$ alle retninger: forskning, metoder, evidens, ontologi, forskningens (mulige) nytte for praksis, mål og midler, kausalitet, etiske overveielser, rom for skjønn, elevenes rolle, praktikernes rolle, etc. Det er kanskje bare å forvente at uenigheten er stor, og at bølgene går høyt. Jeg har prøvd å balansere et sted i midten som best jeg kan. Hovedsakelig synes jeg at deler av kritikken mot EBP er feilrettet (f.eks. kausalitet og instrumentalitet), samtidig som andre kritikkverdige trekk ofte går under radaren (f.eks. begrensningen i RCT-data og at framforskning av årsaker er noe annet enn å bruke disse årsakene (tiltakene, midlene) til å frambringe ønskverdige resultater). Det er naturligvis også flere ting å si om EBP enn jeg har sagt her - et tema som er så mangfoldig, blir knapt uttømt for emner som kan diskuteres.

EBP er praksisrettet i navnet, men er likevel mest innrettet mot forskning og metode. Forskning kan gi oss verdifull kunnskap om hva som har virket på bestemte steder (der undersøkelsene ble utført). Det er en styrke hvis undersøkelsene er gjort på mange ulike steder, med lignende resultater. Det forteller oss at tiltaket kan gjøre jobben sin i ulike kontekster, med ulike faktorer, noe som tyder på et allsidig og smidig middel med rimelig sannsynlighet for å lykkes andre steder. Forskere gjør 


\section{Tone Kvernbekk}

praktikere en stor tjeneste ved å beskrive hvilke faktorer intervensjonen var omgitt av da den ble testet, og som bidro til at den virket (hvis det var det man vurderte at den gjorde). Praksis er mye mer komplisert enn forskning, og den forskningsbaserte evidensen forteller bare halve historien. Resten må praktikerne fylle inn. Det er med andre ord et betydelig rom for praktikerne og deres kunnskaper, skjønn og praktiske oppfinnsomhet i EBP. Jeg er derfor egentlig ikke bekymret for praktikernes skiønn, det er mye mer rom for det enn både kritikere og tilhengere tror.

Det er også viktig å sette grensene for hvor EBP kan bidra, og hva den kan bidra med. EBP kan naturligvis bidra når det er snakk om leseopplæringsmetoder, bruken av feedback og andre mer konkrete ting hvor instrumentell tenkning er fornuftig gitt at både forskere og praktikere forstår at begge parter har noe å bidra med til avveiningene som skal giøres og beslutningene som skal tas.

\section{Referanser}

Achinstein, P. (2001). The Book of Evidence. Oxford: Oxford University Press.

Arnesen, A., Ogden, T. \& Sørlie, M.-A. (2006): Positiv atferd og støttende laringsmiljø $i$ skolen. Oslo: Universitetsforlaget.

Audi, R. (1991). Practical Reasoning. London: Routledge.

Bateson, G. (1972). Steps to an Ecology of Mind. New York: Ballantine Books.

Biesta, G. (2007). Why "what works" won't work: Evidence-based practice and the democratic deficit in educational research. Educational Theory, 57(1), 1-22.

Biesta, G. (2010). Why «what works» still won't work: From evidence-based education to value-based education. Studies in Philosophy and Education, 29(5), 491-503.

Cartwright, N. (2007). Are RCTs the gold standard? BioSocieties, 2(1), 11-20.

Cartwright, N. \& Hardie, J. (2012). Evidence-Based Policy. A Practical Guide to Doing it Better. Oxford: Oxford University Press.

Davies, B. (2003). Death to critique and dissent? The policies and practices of New Managerialism and of «evidence-based practice». Gender and Education, 15(1), 1, 91-103.

Dean, C. B., Hubbell, E.R., Pitler, H. \& Stone, Bj. (2012). Classroom Instruction that Works. Research-Based Strategies for Increasing Student Achievement (2. utg.). Denver: McREL (Mid-continent Research for Education and Learning).

Elliott, J. (2004). Making evidence-based practice practical. I G. Thomas \& R. Pring (Red.), Evidence-Based Practice in Education (s. 164-186). Maidenhead: Open University Press.

Gamson, D. (2007). Historical perspectives on democratic decision making in education: Paradigms, paradoxes, and promises. I Moss, P. (Red.), Evidence and Decision Making. $106^{\text {th }}$ Yearbook of the National Society for the Study of Education (s. 15-45). Malden, MA og Oxford: Blackwell Publishing.

Hammersley, M. (1997). Educational research and teaching: A response to David Hargreaves' TTA lecture. British Educational Research Fournal, 23(2), 141-161.

Hammersley, M. (Red.) (2007). Educational research and evidence-based practice. Los Angeles: SAGE.

Hargreaves, D. (1996a). Teaching as a research-based profession: Possibilities and prospects. Teacher Training Agency Annual Lecture, London.

Hargreaves, D. (1996b). Educational research and evidence-based educational practice - a response to critics. Research Intelligence, 58(November), 12-16.

Hattie, J. (2009). Visible learning: A synthesis of over 800 meta-analyses relating to achievement. London: Routledge. Hattie, J. (2012). Visible learning for teachers. Maximizing impact on learning. London: Routledge.

Hitchcock, D. (2011). Instrumental rationality. I P. McBurney, I. Rahwan \& S. Parsons (Red.), Argumentation in Multi-Agent Systems (s. 1-11). New York/Heidelberg: Springer.

Kelly, T. (2008). Evidence. I E. Zalta (Red.), Stanford Encyclopedia of Philosophy. Hentet fra http://plato.stanford. edu/entries/evidence/ 
Kvernbekk, T. (2016). Evidence-based Practice in Education. Functions of evidence and causal presuppositions. London: Routledge.

Løngreen, H. (2014). Pædagogik mellom manual og mavefornemmelse. Asterisk, (69), 2.

Nordahl, T. (2010). Læringsmiljøets betydning og bruk av veiledningsmateriellet. Hentet fra https://www. slideshare.net/udir/bedre-lringsmilj-lringsmiljets-betydning-thomas-nordahl.

Oancea, A. \& Pring, R. (2008). The importance of being thorough: On systematic accumulation of "what works» in education research. Fournal of Philosophy of Education, 42(Supplementary Issue 1), 15-39.

Rømer, T. Aa. (2012). Pædagogik og evidens. Pæedagogisk Psykologisk Tidsskrift, 49(3), 176-186.

Sanderson, I. (2003). Is it "what works» that matters? Evaluation and evidence-based policy-making. Research Papers in Education, 18(4), 331-345.

Skjervheim, H. (1992). Det instrumentalistiske mistaket. I Skjervheim, H. (Red), Filosofi og dømmekraft (s. 172-178). Oslo: Universitetsforlaget. Artikkel først publisert 1972.

Slavin, R. E. (2002). Evidence-based education policies: Transforming educational practice and research. Educational Researcher, 31(7), 15-21.

Slavin, R. E. (2004). Education can and must address «what works» questions. Educational Researcher, 33(1), $27-28$. 